\title{
EFEKTIFITAS PELATIHAN KEBERSYUKURAN UNTUK MENINGKATKAN KUALITAS HIDUP PADA PASIEN HIPERTENSI
}

\author{
Indahria Sulistyarini 1 \\ Program Studi Psikologi Universitas Islam Indonesia
}

\begin{abstract}
Gratitude training is one of the Islamic intervention that is able to improve quality of life in hypertension patients. It applied quasy experimental design with pretest-posttest with control group design. Participants consist of 23 hypertension patients and at least diagnosed for 1 year. The result showed that gratitude training able to improved quality of life in hypertension patients. This indicated by increasing the score of quality of life in experiment group ( $M D=-18.833, p=0.000$ on pretest to posttest; $M D=-28.417, p=0.000$ on pretest to follow up). MD's negative value indicates that the mean score of the quality of life during posttest and follow up was higher than the mean score during pretest. It means gratitude training can be used to improve quality of life in hypertension patients. So it can also a companion to medical intervention.
\end{abstract}

Keywords: Gratitude Training, Quality of Life, Hypertension

\begin{abstract}
ABSTRAK: Penelitian kebersyukuran adalah salah satu terapi islam yang dapat digunakan untuk meningkatkan kualitas hidup pada pasien penyakit hipertensi. Desain penelitian ini adalah quasi eksperimen pretest-pascatest control group. Subjek dalam penelitian berjumlah 23 orang dan telah terdiagnosa mengalami hipertensi minimal 1 tahun. Hasil dari penelitian ini menunjukkan bahwa pelatihan kebersyukuran dapat meningkatkan kualitas hidup pasien hipertensi yang ditunjukkan dengan peningkatan skor kualitas hidup pada kelompok eksperimen $(\mathrm{MD}=-18.833$, $\mathrm{p}=0.000$ dan prates-tindak lanjut $(\mathrm{M}=-28.417, \mathrm{p}=0,000)$. MD yang negatif mengindikasikan bahwa skor pascates dan tindak lanjut lebih tinggi daripada skor prates. Hal ini berarti bahwa pelatihan kebersyukuran dapat meningkatkan kualitas hidup pada pasien hipertensi, sehingga dapat dijadikan juga sebagai pendamping dari terapi medis.
\end{abstract}

Kata kunci: Pelatihan Kebersyukuran, Kualitas hidup, Hipertensi.

\footnotetext{
${ }^{1}$ Korespondensi mengenai isi artikel dapat dilakukan melalui: $\underline{033200101 @ u i i . a c . i d}$
} 
Hipertensi adalah salah satu jenis penyakit kronik yang menimbulkan masalah di dunia. Kemunculan penyakit ini seringkali tanpa disertai dengan keluhan sehingga pasien tidak mengetahui jika pasien mengalami hipertensi dan akhirnya baru diketahui setelah terjadi komplikasi. Sebagai penyakit silent killer, hipertensi dapat menjadi pintu masuk bagi penyakit lainnya seperti jantung, gagal ginjal dan stroke.

Data World Health Organization (WHO) tahun 2015 menunjukkan sekitar 1,13 Miliar orang di dunia menyandang hipertensi, artinya 1 dari 3 orang di dunia terdiagnosis hipertensi. Jumlah penyandang hipertensi terus meningkat setiap tahunnya, diperkirakan pada tahun 2025 akan ada 1,5 Miliar orang yang terkena hipertensi, dan diperkirakan setiap tahunnya 9,4 juta orang meninggal akibat hipertensi dan komplikasinya. Berdasarkan data dari Riskesdas (2018), angka kematian di Indonesia akibat hipertensi cukup besar dan prevalensi penyakit hipertensi setiap tahunnya terus meningkat. Hipertensi menempati urutan pertama terbanyak dibandingkan dengan penyakit kronik lainnya dan DIY menempati urutan kedua tertinggi dibandingkan dengan seluruh wilayah di Indonesia.

Penyakit hipertensi telah menimbulkan dampak terhadap kualitas hidup pasien. Banyak penelitian yang telah dilakukan yang untuk mengetahui bagaimana kualitas hidup pada pasien hipertensi. Mayoritas, menemukan bahwa pasien yang mengalami hipertensi memiliki kualitas hidup yang buruk. Penelitian yang dilakukan Bhandari, Buksal, Takma and Lawot (2016) menunjukkan bahwa jumlah pasien hipertensi di Katmandu terus meningkat dan hal tersebut berdampak pada kualitas hidup yang buruk terutama pada domain fisik dan psikologis. Penelitian lain yang dilakukan kepada pasien hipertensi adalah penelitian Xiao, Zhang, Xiao, Bu, Tang, Long (2019) yang mencoba mengkaitkan antara usia dan tingkat pendidikan sebagai variabel yang berpengaruh terhadap kualitas hidup. Penelitian ini menemukan bahwa pasien perempuan yang berusia lanjut memiliki kualitas hidup yang rendah. Lebih lanjut penelitian ini menemukan bahwa usia, jenis kelamin dan beban ekonomi yang dirasakan merupakan faktor yang mempengaruhi hipertensi sementara aktivitas fisik, penggunaan alkohol dan regulasi emosi lebih berhubungan dengan kualitas hidup.

Penelitian yang dilakukan di Indonesia juga menunjukkan hal yang sama. Penelitian yang dilakukan Khoirunnisa dan Akhmad (2019) menunjukkan bahwa kualitas hidup pada pasien hipertensi pada aspek psikologis lebih rendah dibandingkan aspek fisik. Faktor usia memiliki kontribusi dalam domain fisik dibandingkan domain psikologis. Kondisi tersebut pada akhirnya akan menimbulkan ketidaknyamanan dan menimbulkan turunnya kualitas hidup pasien hipertensi. Padahal kualitas hidup yang baik pada pasien penyakit hipertensi sangat diperlukan untuk mendapatkan status kesehatan terbaiknya dan mempertahankan fungsi atau kemampuan fisiknya seoptimal mungkin dan selama mungkin. Berdasarkan hasil wawancara dengan subjek yang mengalami hipertensi diperoleh data bahwa selama ini penyakit hipertensi yang dimiliki oleh pasien telah memberikan efek negatif terhadap kehidupannya, meliputi aspek fisik, emosional, dan sosial pada kehidupan sehari-hari melalui keluarga, kerja, dan hubungan sosial. Lingkungan keluarga \& kesehatan psikologis penderita adalah aspek-aspek yang paling berpengaruh bagi penderita \& kerabatnya. Setelah mengalami hipertensi, subjek mulai merasa ada pembatasan-pembatasan aktivitas yang membuat subjek tidak mampu menjalankan fungsinya dengan optimal.

Berdasarkan data tersebut dapat disimpulkan bahwa pasien yang mengalami hipertensi memiliki kualtas hidup yang buruk. Hal ini diperkuat dengan pernyataan 
yang diungkapkan Barile, dkk (2013) bahwa kondisi individu dengan sakit hipertensi telah diasosiasikan dengan berbagai batasan dalam melakukan aktivitas keseharian. Berbagai batasan tersebut kemudian diasosiasikan dengan memburuknya kualitas hidup individu yang bersangkutan.

Kualitas hidup merupakan suatu konsep yang luas dan dengan cara yang kompleks dipengaruhi oleh kondisi fisik, psikologis, tingkat kemandirian, hubungan sosial dari individu dan hubungannya dengan berbagai segi yang penting dari lingkungan (Lopez \& Snyder, 2006). World Health Organization Quality of Life Group (WHOQOL-BREFF) mendefinisikan kualitas hidup sebagai persepsi individu tentang keberadaannya di kehidupan dalam konteks sistem nilai dan budaya dimana individu tersebut tinggal dan hubungannya dengan berbagai, tujuan, harapan, standar, dan halhal lain yang menjadi perhatian individu.

Banyak faktor yang mempengaruhi kualitas hidup, salah satunya adalah kebersyukuran. Penelitian yang dilakukan Sulistyarini dan Andriansyah (2019) terhadap 152 pasien kronik yang salah satunya adalah pasien hipertensi menunjukkan bahwa selain dukungan sosial, kebersyukuran merupakan faktor yang berperan dalam kualitas hidup pasien kronik. Hasil yang sama juga ditemukan dari penelitian yang dilakukan Souza dan Kamble (2016) terhadap 397 pasien kanker yang berusia 36-67 tahun. Hasil penelitian tersebut menemukan bahwa spiritualitas dan kebersyukuran merupakan prediktor yang kuat terhadap kualitas hidup. Penelitian yang dilakukan Valikhani, Ahmadnia, Krimi dan Mils (2019) menyebutkan bahwa kebersyukuran melalui mediator stres dan kesehatan mental berpengaruh terhadap kualitas hidup. Sama hal nya dengan penelitian yang dilakukan Ghalesefidi, Maghsoudi, Pouragha (2019) terhadap 64 pasein yang mengalami ketergantungan obat, menemukan bahwa kebersyukuran dapat meningkatkan bukan hanya kesejahteraan psikologis namun juga kualitas hidup selama program tritmen berlangsung

Berdasarkan penelitian-penelitian di atas, maka dapat disimpulkan bahwa kebersyukuran memiliki korelasi dengan kualitas hidup. Atas dasar itu, peneliti tertarik untuk mengambil konsep tentang kebersyukuran dalam intervensi yang akan dilakukan. Dasar yang menjadi alasan lainnya adalah karena intervensi yang menggunakan pendekatan spiritualitas atau religiusitas masih terbatas jumlahnya. Kebersyukuran merupakan salah satu konsep yang penting dalam religiusitas atau spiritualitas individu. Kebersyukuran (gratitude) berasal dari bahasa latin "gratia" yang memiliki arti doa atau berterima kasih. Kata tersebut mengandung makna segala perilaku yang dilakukan dengan keramahan, murah hati, pemberian, keindahan dari memberi dan menerima, dan melakukan sesuatu tanpa pamrih (Emmons \& Mc Cullough, 2003). Sedangkan dalam Islam, kata syukur secara lughawi/bahasa bermakna membuka dan menyatakan. Membuka kenikmatan, menyatakan kenikmatan dan menyebut kenikmatan dengan lisan. Hakikat syukur adalah menggunakan nikmat Allah SWT untuk taat kepadaNya dan tidak menggunakannya untuk berbuat maksiat (Makhdlori, 2007).

Bersyukur sangat penting dalam Islam karena di dalam kata syukur mengandung makna atau pengetahuan yang dapat membangkitkan kesadaran bahwa satusatunya pemberi nikmat dan rahmat serta perlindungan adalah Allah SWT semata. Dengan demikian makna syukur dapat mengungguli semua kriteria pengakuan, seperti taubat, sabar, maupun pengakuanpengakuan lain terkait dengan kesadaran diri. Selain itu, manfaat beryukur itu akan kembali pada orang yang bersyukur itu sendiri. Ketika seseorang dapat mensyukuri nikmat Allah SWT, maka Allah SWT akan 
menambah nikmat lain yang lebih besar. Jadi kedudukan syukur mengisyaratkan kesadaran yang mencakup perihal keluasan rahmat Allah atas hamba-Nya (Makhdlori, 2007). Dalam penelitian ini, peneliti mengambil konsep kebersyukuran menurut Al-Jauziyah. Al-Jauziyah (2005) menjelaskan bahwa syukur dapat dilakukan dengan tiga hal, yaitu: (1) Bersyukur dengan hati atau $q a l b u$, hal ini dapat dilakukan dengan cara meyakini bahwa Allah semata yang memberikan segala macam nikmat sehingga mampu berterima kasih dan menjadikan hati selalu terjaga dari segala penyakit hati, tidak mengeluh, tidak mudah marah dan mampu mengontrol diri dengan baik; (2) Bersyukur dengan lisan, merupakan sarana untuk mengungkapkan hal yang terdapat di hati; (3) Bersyukur dengan perbuatan adalah mengerjakan amal baik dengan cara memaksimalkan segala fungsi anggota tubuh untuk perbuatan yang positif.

Melalui pelatihan kebersyukuran diharapkan pasien dapat mensyukuri nikmat yang telah diberikan oleh Allah SWT serta menerima apa pun secara ikhlas yang diberikan oleh Allah kemudian menggunakan dan mengelola nikmat yang ada secara baik. Bersyukur tidak hanya pada kondisi tertentu atau berkaitan dengan hal yang disukai atau disaat mendapatkan sesuatu saja, melainkan menerima dan mensyukuri semua nikmat yang telah diberikan Allah SWT, karena Allah SWT selalu memberikan hikmah dibalik semua kejadian dan nikmat yang diberikan. El Firdausy (2010) mengatakan bahwa pelatihan keberyukuran membawa dampak positif dalam beragam sisi kehidupan. Penelitian yang dilakukan Emmon \& Misra (2012) menyebutkan bahwa kebersyukuran memiliki kontribusi terhadap kesehatan fisik dan mental. Penelitian yang dilakukan Jackowska, Brown, Ronaldo dan Steptoe (2016) menemukan bahwa intervensi kebersyukuran lebih berpengaruh terhadap kesehatan mental yaitu menurunkan depresi dibandingkan kesehatan fisik. Melalui tulisannya Beken, Jacob, Janssens, Peerters, Reijnders, Lechner and Lataster (2019) mengatakan bahwa banyak penelitian yang telah dilakukan berkaitan dengan kebersyukuran. Mayoritas dari penelitian tersebut menemukan bahwa intervensi kebersyukuran lebih banyak memberikan dampak terhadap aspek psikologis dan mencegah terjadinya penurunan kesejahteraan emosional dibandingkan dengan dimensi psikopatologi atau kesehatan mental. Untuk menjembatani dua hasil penelitian tersebut, peneliti memaparkan penelitian yang dilakukan Yu, Cai, Shen, Gao \& Zhou (2016) yang dilakukan di laboratorium. Hasil penelitian menunjukkan bahwa ketika seseorang menuliskan 3 hal baik dalam hidup yang patut disyukuri ternyata hal tersebut berdampak terhadap kesehatan fisik dan mentalnya.

Berdasarkan uraian di atas, maka dapat disimpulkan bahwa intervensi yng dibungkus dalam konsep kebersyukuran memberikan pengaruh yang kuat terhadap peningkatan kondisi fisik dan emosional pasien. Oleh karena itu, peneliti tertarik untuk melihat pengaruh kebersyukuran terhadap kualitas hidup yang didalamnya tidak hanya terdapat domain fisik dan psikologis, tapi juga hubungan sosial dan lingkungan.

\section{Hipotesa}

Berdasarkan uraian di atas maka hipotesa yang diajukan dari penelitian ini adalah ada peningkatan kualitas hidup pada kelompok yang mendapat perlakuan (eksperimen) dibandingkan dengan kelompok kontrol yang tidak mendapatkan perlakuan. 


\section{METODE PENELITIAN}

\section{Subjek Penelitian}

Subjek penelitian yang akan dilibatkan dalam pelatihan ini merupakan pasien hipertensi dengan karakteristik, telah didiagnosa mengalami sakit hipertensi minimal selama 1 tahun, beragama Islam, memiliki tingkat kualitas hidup yang rendah dan bersedia untuk melakukan rangkaian pelatihan kebersyukuran dalam penelitian ini.

\section{Desain Penelitian}

Penelitian ini merupakan penelitian kuasi eksperimen. Shaughnessy, dkk (2009) merumuskan eksperimen kuasi sebagai eksperimen yang memiliki perlakuan, pengukuran dampak, unit eksperimen, namun tidak menggunakan penugasan acak untuk menciptakan pembandingan dalam rangka menyimpulkan perubahan yang disebabkan oleh perubahan. Desain penelitian yang digunakan adalah pretest posttest control group design, yaitu menggunakan dua kelompok meliputi kelompok eksperimen dan kontrol.

Subjek dalam penelitian ini akan dikelompokkan menjadi dua, yaitu kelompok eksperimen sebagai kelompok pertama dan kelompok kontrol sebagai kelompok kedua. Sebelumnya keseluruhan subjek diminta untuk mengisi skala yang bertujuan untuk mengukur kualitas hidup subjek. Subjek penelitian adalah mereka yang kualitas hidupnya perlu untuk ditingkatkan. Kelompok eksperimen akan diberikan perlakuan berupa pelatihan kebersyukuran, sedangkan kelompok kontrol tidak diberikan perlakuan apapun. Kelompok kontrol diperlakukan sebagai kelompok yang masuk daftar tunggu yang akan mendapatkan pelatihan setelah seluruh proses penelitian berakhir.

Setelah pemberian perlakuan pada kelompok eksperimen selesai dilakukan, subjek pada kelompok ekperimen dan kontrol diminta untuk mengisi skala untuk melihat apakah hasil skor pengukuran kualitas hidup mengalami peningkatan. Kurang lebih dua minggu setelah semua sesi berakhir juga akan dilakukan pengukuran menggunakan skala kualitas hidup sebagai tindak lanjut dengan tujuan untuk melihat efektivitas intervensi yang telah dilakukan. Rancangan penelitian secara umum dapat dijelaskan dalam tabel berikut:

Tabel 1. Rancangan Penelitian

\begin{tabular}{rcccc}
\hline Kelompok & Prates & Perlakuan & Pascates & Tindak lanjut \\
(A) KE & Y1 & $\mathrm{X}$ & Y2 & Y3 \\
(B) KK & Y1 & $\sim \mathrm{X}$ & Y2 & Y3 \\
\hline
\end{tabular}

Keterangan:

(A) : Kelompok Eksperimen

(B) : Kelompok Kontrol

Y1 : Pengukuran prates

Y2 : Pengukuran pascates

Y3 : Pengukuran tindak lanjut

$\mathrm{X}$ : Perlakuan (pelatihan kebersyukuran)

$\sim \mathrm{X}$ : Tanpa diberi perlakuan (waiting list). 


\section{Prosedur Eksperimen}

Pelatihan kebersyukuran akan dibagi menjadi tiga kali pertemuan dan masing-masing pertemuan dibagi dalam 4-6 sesi dalam waktu 60-120 menit (1-2 jam). Pemberian pelatihan kebersyukuran diawali dengan penjelasan tentang prosedur pelatihan, informed consent dan tujuan pelatihan. Pelatihan ini dilanjutkan dengan pemberian penjelasan tentang hubungan antara pikiran, perasaan dan perilaku, lalu peserta diberi kesempatan untuk berbagi pengalaman sehingga menimbulkan kesadaran tentang hal-hal yang berhubungan dengan pikiran, perasaan dan perilaku. Selanjutnya ada pemberian informasi tentang kebersyukuran dan pemberian kesempatan kepada peserta untuk berbagi pengalaman tentang karunia yang telah diterima. Untuk lebih menghayati materi, peserta diberikan tugas rumah yang tidak berat yang nantinya tugas rumah tersebut akan didiskusikan saat peserta bertemu kembali. Kemudian pada pertemuanpertemuan berikutnya dilakukan edukasi oleh dokter terkait dengan penyakit hipertensi.

\section{Metode Pengumpulan Data}

Pengumpulan data dalam penelitian ini memiliki tujuan mengungkap gambaran mengenai variabel yang diteliti. Skala kualitas hidup (WHOQOL-BREF) yang disusun berdasarkan aspek-aspek dari WHO dalam (WHOQOL Group, 1998) berdasarkan aspek-aspek kesehatan fisik, psikologis, hubungan sosial, dan lingkungan. Skala ini terdiri dari 26 aitem. Dari 26 aitem tersebut peneliti menggunakan semua aitem tersebut yang dianggap valid. Dari hasil uji coba skala kualitas hidup memperoleh koefisien reliabilitas Alpha Cronbach dengan nilai $\alpha=$ 0.847. Hal tersebut menunjukkan tingkat konsistensi atau kepercayaan sebesar $80,47 \%$ dan menampakkan variasi error sebesar $19,53 \%$.

\section{HASIL PENELITIAN}

\section{Deskripsi Subjek Penelitian}

Subjek pada penelitian ini adalah pasien hipertensi, berjumlah 23 orang, berjenis kelamin laki-laki dan perempuan, berusia 40-60 tahun, beragama Islam, lama menderita sakit hipertensi minimal 1 tahun. Subjek dibagi menjadi dua kelompok, yaitu 12 orang kelompok eksperimen dan 11 orang kelompok kontrol. Deskripsi subjek dijelaskan pada tabel di bawah ini :

Tabel 2. Deskripsi data Penelitian Kualitas hidup Kelompok Eksperimen dan Kontrol

\begin{tabular}{cccccccccc}
\hline & \multicolumn{3}{c}{ Kelompok Eksperimen } & \multicolumn{5}{c}{ Kelompok Kontrol } \\
\hline Subjek & JK & Prates & Pascates & $\begin{array}{c}\text { Tindak } \\
\text { Lanjut }\end{array}$ & Subjek & JK & Prates & Pascates & $\begin{array}{c}\text { Tindak } \\
\text { Lanjut }\end{array}$ \\
\hline SU & P & 75 & 91 & 102 & NU & P & 82 & 79 & 73 \\
\hline SR & P & 88 & 94 & 111 & AD & P & 77 & 70 & 66 \\
\hline SU & P & 75 & 96 & 104 & KA & P & 72 & 74 & 71 \\
\hline NG & P & 77 & 104 & 104 & IY & P & 95 & 74 & 69 \\
\hline SU & P & 88 & 100 & 108 & PY & L & 74 & 66 & 71 \\
\hline TU & P & 68 & 99 & 105 & NO & L & 77 & 66 & 70 \\
\hline MU & L & 84 & 104 & 100 & IN & P & 73 & 65 & 66 \\
\hline SUR & L & 74 & 111 & 97 & HR & L & 66 & 77 & 69 \\
\hline SA & P & 81 & 83 & 104 & YA & P & 68 & 75 & 64 \\
\hline SR & P & 75 & 90 & 104 & TK & P & 63 & 65 & 70 \\
\hline JU & P & 70 & 88 & 109 & HR & P & 64 & 74 & 67 \\
\hline SRI & P & 57 & 78 & 105 & & & & & \\
\hline
\end{tabular}




\section{Uji Homogenitas pada Kelompok Eksperimen dan Kelompok Kontrol}

Uji homogenitas dilakukan untuk menentukan apakah frekuensi atau proporsi antara variabel dalam satu kelompok yang diujikan tidak berbeda secara signifikan.
Kaidah uji yang digunakan, jika $\mathrm{p}>0,05$ maka variansnya homogen. Jika $\mathrm{p}<0.05$ maka varians tidak homogen. Uji homogenitas dilakukan dengan menggunakan teknik Homogenity of Variance One-Way Anova program SPSS 16.0 for windows.

Tabel 3. Uji Homogenitas data penelitian skala Kualitas Hidup (WHOQL BREF)

\begin{tabular}{cccc}
\hline Kelompok & Levene Statistic & $\mathbf{p}$ & Keterangan \\
\hline Prates Eksperimen dan kontrol & 8.790 & $0.886 ; \mathrm{p}>0.05$ & Homogen \\
\hline
\end{tabular}

Pada tabel hasil uji homogenitas pada skala kualitas hidup (WHOQL BREF) menunjukkan nilai Levene Statistic 8.790 dengan $\mathrm{p}=0,886 \quad(\mathrm{p}>0,05)$. Berdasarkan kaidah, maka dapat dikatakan bahwa tidak ada perbedaan varians data pada saat prates kelompok eksperimen dan kontrol pada subjek penelitian atau homogen.

\section{Uji Hipotesis}

Uji perbedaan dalam penelitian ini menggunaka ANAVA MiX Design. Jika dilihat dari data perbandingan hasil uji hipotesis skala kualitas hidup maka diperoleh tests of within-subjects effects pada baris time group dan sub baris Greenhouse-Geisser menunjukkan nilai $\mathrm{F}=37.447$ dengan $\mathrm{p}=0.000$, yang artinya terdapat interaksi antara time (pra-pasca) dan group (eksperimenkontrol). Adanya interaksi menunjukkan adanya perbedaan yang signifikan pada perubahan skor kualitas hidup antara kelompok eksperimen dan kontrol (pra menuju pasca). Pada data perbandingan (uji beda) antara kelompok eksperimen dan kontrol, hasil analisis data menunjukkan adanya peningkatan yang sangat signifikan pada skor kualitas hidup kelompok eksperimen setelah pra-pascates (MD $=-18833$, $\mathrm{p}=0,000 ; \mathrm{p}<0.01$ ) dan saat tindak lanjut rerata skor kualitas hidup kelompok eksperimen kembali mengalami peningkatan yaitu (MD = -28.417, $\mathrm{p}=0.000 ; \mathrm{p}<0.01$ ). Sementara, pada kelompok kontrol justru mengalami penurunan rerata skor kualitas hidup (MD = 2.364, $\mathrm{p}=0.435 ; \mathrm{p}=0.000 ; \mathrm{p}<$ 0.01 dan pada saat pasca tes dan mengalami penurunan kembali saat tindak lanjut $(\mathrm{MD}=$ 5.000, $\mathrm{p}=0.078 ; \mathrm{p}<0.01$ ).

\section{Pembahasan}

Penelitian ini bertujuan untuk mengetahui pengaruh pelatihan kebersyukuran terhadap peningkatan kualitas hidup yang dialami penderita penyakit kronik, dalam hal ini hipertensi. Hasil yang diperoleh dalam penelitian ini menunjukkan bahwa pelatihan keberyukuran berpengaruh terhadap peningkatan kualitas hidup pasien hipertensi. Hasil penelitian menunjukkan adanya peningkatan yang sangat signifikan pada skor kualitas hidup kelompok eksperimen setelah diberi intervensi. Berdasarkan analisis data yang telah dilakukan maka dapat disimpulkan bahwa ada perbedaan kualitas hidup antara kelompok eksperimen yang diberikan perlakuan pelatihan keberyukuran dengan kelompok kontrol yang tidak diberikan perlakukan berupa pelatihan keberyukuran. Penelitian ini mendukung hasil penelitian McCullough \& Emmons (2013) yang menemukan bahwa kebersyukuran secara empirik dapat mempertahankan dan meningkatkan kualitas hidup, meningkatkan kualitas kepribadian, kesejahteraan psikologi, relasi sosial dan pemecahan masalah ketika seseorang berada dalam kondisi sakit. 
Penelitian lain yang memang tidak langsung memforkuskan sasaran pada kualitas hidup adalah penelitian Jackowska, Brown, Ronaldo dan Steptoe (2016). Penelitian ini dilakukan pada pasien hiprtensi dengan meminta pasien mengekspresikan rasa syukur selama 2 minggu. Hasil penelitian menunjukkan adanya penurunan tekanan darah walaupun hanya tekanan darah diastolic dan meningkatkan kualitas tidur. Kondisi tersebut berpengaruh pada kesejahteraan psikologis pasien.

Kondisi tersebut dapat dipahami karena ketika seseorang berpikir tentang rasa syukur, maka biasanya seseorang berpikir tentang hal-hal yang baik maka akan muncul perasaan kagum kepada Allah. Rasa kagum tersebut memunculkan rasa untuk berterima kasih atas semua nikmat yang telah diterimanya sehingga seseorang akan menerima kondisi sakitnya, apalagi ketika pasien membandingkan kondisinya dengan pasien lain yang penyakitnya lebih parah dibandingkan dengan pasien. Hal ini sesuai dengan yang diungkapkan El Bantanie (2014) bahwa individu akan mudah bersyukur saat membandingkan keadaan dirinya dengan individu lain. Seseorang merasa bahwa beban yang dialaminya jauh lebih ringan dibandingkan dengan beban yang dirasakan oleh orang lain. Akhirnya akan muncul perasaan menerima yang membuat pasien melupakan hal-hal yang tidak nyaman dan membuat pasien hipertensi merasa menjadi lebih baik. Hasil penelitian ini mendukung penelitian yang telah dilakukan McCullough, Tsang, dan Emmons (2004) bahwa seseorang yang bersyukur dapat menerima kondisi dalam keadaan menyenangkan dan tidak menyenangkan. Kondisi perasaan seharihari menjadi lebih stabil, semakin optimis, yang membuat kualitas hidup juga semakin baik. Dengan demikian, dapat dikatakan bahwa seseorang yang memiliki kebersyukuran yang tinggi akan menggunakan strategi koping yang efektif dalam menghadapi permasalahan.

Hal ini didukung hasil studi Emmons (2008) yang mengatakan bahwa seseorang yang terbiasa menghitung nikmat akan lebih mudah untuk bersyukur, merasa optimis, kepuasan hidup meningkat, dan afek negatif menurun. Sebaliknya individu yang tidak terbiasa bersyukur ketika sedang di tengah kesulitan atau konflik membuat individu akan berpikir tentang hal-hal negatif dan selalu mengeluh dengan kondisi yang sedang dialaminya. Ketika seseorang menderita penyakit atau kondisi sulit, maka mereka akan merasakan perubahan pada aspek fisik, emosi, mental dan spiritual. Kebersyukuran juga memiliki hubungan yang negatif dengan koping yang disfungsional dalam bentuk penyimpangan perilaku seperti menyalahkan diri sendiri, penyalahgunaan zat atau obat, dan penyangkalan (denial) (Wood, Joseph, \& Linley, 2007).

Emmons (2007) dalam penelitian lain menyimpulkan, berlatih bersyukur dapat meningkatkan tingkat kebahagiaan sekitar $25 \%$. Hal ini penting, mengingat ada beban tertentu yang terasa alami untuk tubuh seseorang dan berusaha untuk dipertahankan untuk mencapai kebahagiaan. Praktek bersyukur akan meningkatkan tingkat kebahagiaan, sehingga seseorang dapat tetap pada tingkat kebahagiaan yang lebih tinggi terlepas dari apapun keadaan di luar individu tersebut.

Penelitian yang dilakukan Sztachariska, Krejsz dan Neziek (2019) kepada pasien kanker payudara menemukan bahwa intervensi kebersyukuran dapat meningkatkan fungsi dalam keseharian pasien kanker. Pasien yang menuliskan alasan kenapa mereka harus bersyukur setiap hari menunjukkan peningkatan fungsi dalam kesehariannya.

Menurut Lambertt \& Fincham (2011), kebersyukuran secara umum adalah kebersyukuran yang muncul dapat meliputi 
perasaan bersyukur karena bangun tidur di pagi hari, berterimakasih atas kondisi kesehatan seseorang, dan sebagainya. Redwine et al (2016) pada pasien gagal jantung, intervensi kebersyukuran berhubungan dengan peningkatan skor kebersyukuran yang telah dimiliki seseorang dan meningkatkan kerja syaraf parasimpatetik selama pasien diberikan tugas yang terkait dengan kebersyukuran sehingga intervensi kebersyukuran dapat menjadi intervensi tambahan pada pasien yang berusia lanjut. Penelitian yang dilakukan Otto, Szczesny, Soriano, Lurenceau, Siegel (2016) juga mengungkapkan hal yang sama bahwa intervensi kebersyukuran dapat mengurangi ketakutan pasien terhadap kematian karena sakit yang dialami walaupun tidak berefek pada ketakutan akan kematian secara umum.

Berbagai hal yang telah dikemukakan di atas menunjukkan bahwa subjek telah mampu mengungkapkan kebersyukuran secara umum dalam kehidupannya, hal ini menunjukkan bahwa pelatihan kebersyukuran dapat memberikan kontribusi dalam proses pengembangan spiritualitas seseorang, yang selanjutnya dapat berdampak pada kualitas hidup seseorang. Proses pelatihan kebersyukuran ini juga melatih subjek untuk berfokus pada hal-hal positif yang ada di dalam diri meskipun dalam kondisi sakit, sehingga subjek mampu mengungkapkan berbagai hal positif yang diterimanya selama berada dalam kondisi sakit, seperti mendapatkan perhatian atau dukungan dari anggota keluarga, merasa masih diberi kesempatan oleh Allah SWT untuk hidup, dan melalui sakit dapat memperoleh pahala atau diampuni dosa-dosanya. Hal positif lainnya adalah subjek masih dapat memberikan manfaat kepada anggota keluarganya (seperti membantu pekerjaan pasangan- nya), menjadikan diri lebih sabar, rela menerima kondisi, dan lebih bersungguhsungguh dalam menjalani aktivitas. Melalui kondisi sakit, subjek dapat selalu mengingat Allah SWT sebagai sumber pemberi karunia, kondisi sakit merupakan suatu peringatan dan bentuk kasih sayang Allah SWT pada manusia, melatih memunculkan pikiranpikiran yang baik pada Allah SWT, dan menjadikan dirinya semakin mendekatkan diri pada Allah SWT melalui ibadah yang dilakukan sehari-hari.

Impilkasi dari penelitian ini dapat digunakan sebagai salah satu alternatif terapi agama oleh praktisi untuk meningkatkan kualitas hidup pasien dengan penyakit kronik terutama pasien hipertensi. Selain itu, penelitian ini dapat dijadikan rujukan bagi tenaga medis untuk diberikan kepada pasien selain terapi medis yang selama ini telah dilakukan sehingga penanganan terhadap pasien hipertensi akan lebih komprehensif.

\section{SIMPULAN DAN SARAN}

Berdasarkan hasil penelitian maka dapat disumpulkan bahwa pelatihan kebersyukuran efektif dalam meningkatkan kualitas hidup pada pasien dengan hipertensi. Terdapat perbedaan yang signifikan hasil pengukuran sebelum dan sesudah diberikan pelatihan baik pada kedua kelompok. Kelompok eksperimen mengalami peningkatan, sedangkan kelompok kontrol mengalami penurunan kualitas hidup.

Berdasarkan hasil penelitian tersebut maka diharapkan pasien hipertensi selalu bersyukur dengan kenikmatankenikmatan yang diberikan Allah termasuk merasakan nikmat saat diberikan ujian sakit sehingga kualitas hidup yang telah meningkat akan tetap dapat dipertahankan. 


\section{DAFTAR PUSTAKA}

Al-Jauziyah, I.A.Q. (2005). Kemuliaan Sabar dan Keagungan Syukur. Mitra Pustaka: Yogyakarta

Barile J.P., Thompson, W.W., Zack, M.M. Krahn, G.L., Johnson, W.H., and Bowen, S.E. (2013). Multiple chronic medical conditions and Health-Related Quality of Life in older adults, 2004-2006. Journal of Preventing Chronic Disease, 10, 1-11.

Bandhari, N., Bhusal, B.R., Takma.K.C., Lawot, I. (2016). Quality of life of patient with hypertension in Kathmandu. International Journal of Nursing Science. 3, 379-384

Beken, LJ.JJacobs, N.,Janssens, M.,Peetres, S.,Reijndres, J., Lechner, L \& Lataster, J. (2019) Gratitrde and health : An updates review. Journal of Positive Psychology, Doi : 10.1080/17439760. 2019.1651888

Emmons, R. A., \& Mishra, A. (2012). Why gratitude enhances well-being: What we know, what we need to know. In Sheldon, K., Kashdan, T., \& Steger, M.F. (Eds.) Designing the future of positive psychology: Taking stock and moving forward. New York: Oxford University Press

Emmons, R. A. (2008). Gratitude, subjective well-being, and the brain. In R.J. Larsen \& M. Eid (Eds.), The Science of Subjective

Emmons, R.A. (2007). Pay it forward : A symposium on gratitude. Greater good, $4,12-15$

Emmons, R.A., \& McCullough, M.E. (2003). Counting Blessings Versus Burdens: An experimental investigation of gratitude and subjective well-Being in daily Life. USA: APA Journal of Personality and Social Psychology, 84, 2, 377-389
Emmons, R.A., McCullough, M.E. (2004). The Psychology of gratitude. New York: Oxford University Press, Inc. 198 Madison Avenue

El-Bantanie, M. S. (2014). Sabar tanpa batas, syukur tanpa ujung. Jakarta: PT. Gramedia.

El-Firdausy, M. I. (2010). Rahasia dahsyatnya syukur. Jawa Tengah: One Books.

Ghalesefidi, M.J., Maghsoudi, J.,Pouragha. B. (2019). Effectivitiveness of gratitude on psychological well being and quality of life among hospitalized substance abuse patients. Electron Journal of general Medicine, 16 (2), 17, Doi : 10.29333/ejgm/94091

Jackowska, M.,Brown, J., Ronaldson, A.,\& Stephtow, A. (2016). The impact of a brief gratitude intervention on subjective well being, biology and sleep. Journal of Health Psychology, doi: 10.1177/1359105572455

Kementrian Kesehatan. 2018. Riset Kesehatan Dasar. Jakarta: Badan Penelitian dan Pengembangan Kesehatan Kementrian Kesehatan RI

Khairunisa, S.M.,Akhmad, A.D. (2019). Quality of Life of patients with hypertension in primary helath care in Bandar Lampung, Indonesian Journal of Pharmacy. 30, 309-315

Lambertt, N. M.,\& Fincham, F.D. (2011). Expressing gratitude to a partner leads to more relationship maintenance behavior. Emotion, 11 (1), 52-60

Lopez, S.J. Snyder, C.R. (2006). Positive psychological assessment: A handbook of models and measures. Washington: American Psychological Association. 
McCullough,M.,\&Emmons, R.A. (2013). The Psychology of gratitude mental hiegines es Pszichoszomatika, 14, doi.org/10.1556/Mental.14.2013.2.3

McCullough, M.E., Tsang, J.A. \& Emmons, R.A. (2004). Gratitude in intermediate affective terrain: links of grateful moods to individual differences and daily emotional experience. Journal of Personality and Social Psyhcology, Vol. 86, 295-309

Makhdlori, M. (2007). Bersyukurlah maka engkau akan kaya. Yogyakarta: Diva Press.

Otto, A. K., Szczesny, E.C.,Soriano, E. C.,Lurenceau, J.P., Siegel, S.D. (2016). Effect of a randomized gratitude intervention on death-related fear of recurrence in breast cancer survivor. Health Psychology, 35 (12), 1320-1328

Redwine, L.,Henry,B.L.,Pung, M.A.,Wilson, K.,Chinh, K.,Knight, B.,Jain,S.,Rutledge, T.,Greenberg, B., Maisel, A.,Mills, P.J. (2019). A pilot randomized study of grartitide journaling intervention on HRV and inflammatory biomarkers in stage B heart failure patients. Psychosomatic Medicine, 78(6), 667676. Doi : 10.1097 / PSY. 000000000 00316

Riskesdas. (2018). Badan Penelitian dan Pengembangan Kesehatan Kementrian Kesehatan RI. Laporan Hasil Riset Kesehatan Dasar Indonesia (Riskesdas).

Souza, A.,Kamble,S. (2016). Spirituality and gratitude as predictors of quality of life in adult cancer pastients, The International Journal of Indian Psychology, 3, 2, 40-47
Sulistyarini, I.,\& Adrianyah, Y. (2019). Sosial Support, gratitude and Quality of Life of patients with chronic disease in Yogyakarta, Indonesia. Psychology and Education Journal, 56, 1,2

Sztachanska, J., Krejtz, I.,Nezlek, J.B. (2019). Using a Gratitude Intervnetion to improve the lives of woman with breast cancer : a daily diary study. Original Research Article, 10,1-11. Doi : 10.3389/fpsyg.2019.01365

The WHOLQOL Group. (1998). Development of the World Health Organization WHOQOL-BREF quality of life assessment. The WHOQOL Group. Psychol Med, Vol. 28, No. 3, p 551-558.

Valikhani, A.,Ahmadnia, F., Karimi, A., Milss. P.J. (2019). The Relationship between dispositional gratitude and quality of life : the mediating role of perceived stress and mental health. Personality and Individual Differences, 141, 40-46. Doi : 10.1016/j.paid.2018.12.014

WHO. (2015). Global status reprt on noncommunicable diseases. World Health

Wood, A.M., Joseph,S. \& Linley,P. (2007). Coping style as psychological resource of grateful people. Jurnal of Social and Clinical Psychology.9.1097-1093.

Xiao, M., Zhang., Xiao,N.,Bu.X.,Tang, X.,Long,Q. (2019). Helath-Related Quality of Life of hypertension patients : A population-based crosssecsional study in Chongqing, China. International Journal of Environmental Research and Public Health, 16, 2348; doi : 10.3390/ijerph16132348

Yu, H., Cai, Shen, B.,Gao,X \& Zhou, X. (2016). Neural substances and social qonsequences of interpersonal gratitude : Intention Matters. Emotion. Doi : $10.1037 / \mathrm{emo} 0000258$ 
Indahria Sulistyarini 